20

\title{
Спектроскопическое исследование кинетики высвобождения водонерастворимого препарата гризеофульвин из ватеритных контейнеров в водной среде
}

\author{
(C) М.С. Савельева ${ }^{1}$, Е.В. Ленгерт ${ }^{1}$, А.М. Абрамова ${ }^{2}$, С.Н. Штыков ${ }^{2}$, Ю.И. Свенская ${ }^{1}$ \\ ${ }^{1}$ Образовательно-научный институт наноструктур и биосистем, Саратовский национальный исследовательский \\ государственный университет, \\ 410012 Саратов, Россия \\ ${ }^{2}$ Институт химии, Саратовский национальный исследовательский государственный университет, \\ 410012 Саратов, Россия \\ e-mail: mssaveleva@yandex.ru
}

Поступила в редакцию 07.12.2020 г.

В окончательной редакции 06.01.2021 г.

Принята к публикации 26.02.2021 г.

\begin{abstract}
Разработка подходов, обеспечивающих повышение биодоступности гидрофобных лекарственных препаратов, является одной из приоритетных задач медицинского материаловедения и фармацевтики. Одним из таких подходов является инкапсулирование препаратов в объеме биосовместимых микро- и наноконтейнеров, позволяющих осуществлять адресную доставку препарата, снижать вводимую дозу и её токсическое действие и повышать фармакологический эффект. Важным этапом при применении капсулированных препаратов является исследование кинетики высвобождения лекарственного средства in vitro в модельных средах. Поскольку гидрофобные лекарственные вещества обладают низкой биодоступностью и слаборастворимы либо нерастворимы в воде, то модельные водные среды не позволяют получать полной информации о кинетике высвобождения препарата из контейнера. Для решения данной проблемы нами на примере антимикотика „гризеофульвин“ (Гф) разработана методика комплексного спектроскопического и электронномикроскопического исследования процесса высвобождения данного водонерастворимого препарата из ватеритных микроконтейнеров. Добавление диметилформамида (ДМФА) в качестве полярного органического растворителя к водной суспензии частиц ватерита, содержащих Гф, непосредственно перед измерением спектров поглощения обеспечило повышение правильности и точности определения концентрации высвободившегося препарата в разные промежутки времени. Продемонстрирована корреляция данных, полученных при исследовании кинетики высвобождения препарата в воде данным способом, с результатами мониторинга состояния контейнеров в воде методами сканирующей электронной микроскопии и спектроскопии комбинационного рассеяния.
\end{abstract}

Ключевые слова: УФ, видимая, КР-спектроскопия, адресная доставка лекарств, микроконтейнеры ватерита, гризеофульвин, кинетика высвобождения.

DOI: $10.21883 /$ OS.2021.06.50976.5k-21

\section{Введение}

Методы молекулярной спектроскопии вследствие простоты, возможности идентификации и количественного контроля содержания лекарственных веществ, имеющих органическую природу, широко применяются в фармацевтике и медицине [1,2]. По этой причине методы ИК, УФ, видимой спектроскопии и флуоресценции, а также оптической микроскопии включены в современную фармакопею России [3], международную европейскую фармакопею [4] и фармакопею таких стран как США или Япония [5].

Спектроскопические методы применяют также при разработке новых подходов к адресной доставке лекарственных веществ, которая повышает их биодоступность и увеличивает локальную концентрацию вблизи пораженного органа, снижает токсическое действие препаратов, особенно малорастворимых в воде [6]. К та- ким препаратам относятся, например, различные противогрибковые соединения, ограниченная растворимость которых обусловливает их низкую биодоступность и, следовательно, сниженную терапевтическую эффективность препаратов [7]. Некоторые противогрибковые препараты, например гризеофульвин (Гф), обладают плохой растворимостью не только в воде, но и в этаноле $[8,9]$, поэтому на фармакологическом рынке они представлены исключительно в виде пероральных форм (таблетки, порошки, капсулы или суспензии) $[10,11]$.

Одним из подходов, направленных на повышение биодоступности и снижение системной токсичности водонерастворимых противогрибковых препаратов, является применение различных контейнеров-носителей. В частности, для адресной доставки антимикотиков предложены носители на основе липосом [12], мицелл [13], эмульсий [14-16], везикул [17] различных типов нано- $[18,19]$ и микрочастиц [20-22]. Применение 
таких форм обеспечивает увеличение глубины проникновения и эффективности локализации антимикотика в целевой области, а также продлевает терапевтический эффект, что улучшает биодоступность и одновременно сокращает суммарную терапевтическую дозу препарата [23].

При разработке таких носителей необходимым этапом является предварительное исследование их поведения в модельных средах in vitro. Особенно важно исследование процессов высвобождения лекарственных препаратов из носителей в дисперсных средах, имитирующих биологические жидкости, включая физиологический раствор $(0.15 \mathrm{M} \mathrm{NaCl})$, фосфатно-солевой буфер, питательные среды для культивирования клеток и сыворотку крови. Поскольку такие жидкости представляют собой водные растворы, то исследование высвобождения капсулированных малорастворимых лекарственных форм в воде является нетривиальной задачей, требующей разработки подходов к её решению. В частности, для вышеупомянутого противогрибкового препарата Гф исследовали процесс его высвобождения из носителей только в гидрофобных средах [24], поэтому данные о его высвобождении в водных растворах отсутствуют. Однако комплексное изучение поведения систем адресной доставки и моделирование физиологических процессов требуют накопления информации о растворимости капсулированных лекарственных форм в водных средах.

Ранее мы продемонстрировали возможность иммобилизации Гф в субмикронные контейнеры-носители на основе мезопористых сферических частиц карбоната кальция $\left(\mathrm{CaCO}_{3}\right)$ в метастабильной полиморфной модификации ватерита $[21,25]$. При исследовании процесса высвобождения иммобилизованного антимикотика в воде, физиологическом растворе и культуральной среде возникла проблема образования кристаллов гидрофобного Гф, высвободившихся из ватеритной матрицы, что затрудняло количественную оценку его перехода в водную среду. Образование осадка искажало данные о концентрации антимикотика в исследуемых суспензиях.

Цель настоящей работы состояла в исследовании эффективности высвобождения Гф из микрочастиц ватерита в воде методами УФ, КР- и флуоресцентной спектроскопии. Для увеличения растворимости данного антимикотика до молекулярного состояния к водной суспензии частиц добавляли полярный растворитель. Данные о кинетике высвобождения Гф подтверждали исследованием морфологии микроконтейнеров в процессе инкубации в воде методом сканирующей электронной микроскопии, а также данными мониторинга их состояния методом спектроскопии КР. Это позволило сделать вывод, что разработанный подход позволяет провести оценку и получить адекватное представление о поведении ватеритных контейнеров с Гф в водной среде.

\section{Материалы и методы}

\section{Синтез микроконтейнеров с Гф}

Микроразмерные частицы ватерита, содержащие противогрибковый препарат Гф (Sigma-Aldrich, США), синтезировали за счет совместного осаждения препарата в процессе формирования частиц ватерита в среде этиленгликоля (Sigma-Aldrich, США) [21]. Гризеофульвин предварительно растворяли в этиленгликоле. Для повышения эффективности растворения антимикотика и получения гомогенного раствора с концентрацией $2 \mathrm{mg} / \mathrm{mL}$ раствор обрабатывали в ультразвуковой ванне Сапфир (Россия) с частотой $35 \mathrm{kHz}$ и плотностью мощности $0.64 \mathrm{~W} / \mathrm{cm}^{2}$ в течение $1 \mathrm{~h}$ при температуре $50^{\circ} \mathrm{C}$. После этого одинаковые объемы эквимолярных водных растворов дигидрата хлорида кальция $\left(\mathrm{CaCl}_{2} \cdot 2 \mathrm{H}_{2} \mathrm{O}\right.$, Sigma-Aldrich, США) и карбоната натрия $\left(\mathrm{Na}_{2} \mathrm{CO}_{3}\right.$, Sigma-Aldrich, США) смешивали с раствором Гф в этиленгликоле в соотношении 1:5, а затем между собой. Смешивание растворов проводили на магнитной мешалке IKA RO 10 (Германия) при скорости $700 \mathrm{rpm}$ в течение $2.5 \mathrm{~h}$ при температуре $25-30^{\circ} \mathrm{C}$. По окончании твердую фазу ватерита с включенным Гф отделяли от жидкой на центрифуге Eppendorf 5810 R (Австрия) при скорости $5000 \mathrm{rpm}$ в течение $10 \mathrm{~min}$ с последующей трехкратной промывкой водой и однократной промывкой 70\%-ным этанолом для удаления остатков этиленгликоля и избыточных ионов солей. Полученные контейнеры высушивали при температуре $60^{\circ} \mathrm{C}$ в течение $1 \mathrm{~h}$.

Дзета-потенциал полученных контейнеров измеряли с помощью прибора ZetaSizer Nano ZS (Malvern, Великобритания).

\section{Инкубация в воде контейнеров с Гф}

Для исследования процесса высвобождения Гф из ватеритных контейнеров использовали деионизованную воду, полученную на установке Milli-Q Purification System (Millipore, Merck, США). К навескам массой $3.3 \mathrm{mg}$ микроконтейнеров с антимикотиком добавляли $0.7 \mathrm{~mL}$ воды, после чего образцы помещали в шейкер Digital Shaking Drybath (Termo Scientific, США) при температуре $25^{\circ} \mathrm{C}$ и скорости перемешивания $700 \mathrm{rpm}$.

\section{Исследование морфологии контейнеров при инкубации}

Мониторинг состояния контейнеров в процессе их инкубации в воде осуществляли с помощью сканирующей электронной микроскопии (СЭМ) на приборе MIRA II LMU (Tescan, Чехия) при рабочем напряжении $20 \mathrm{kV}$. Для этого капли суспензии контейнеров объемом $1 \mu \mathrm{L}$ из каждого образца наносили на кремниевую подложку и изучали морфологическую структуру частиц ватерита, содержащих антимикотик Гф. 


\section{Изучение кинетики высвобождения Гф}

При исследовании процесса высвобождения Гф из частиц ватерита в воде в качестве полярного растворителя, добавляемого к водной суспензии частиц для его растворения перед измерением, была проведена апробация протонного растворителя этанола и апротонного ДМФА, обладающих разным механизмом растворения Гф.

На первом этапе кинетику высвобождения Гф из микроконтейнеров в воде изучали, измеряя интенсивность флуоресценции аликвоты раствора в каждый конкретный момент времени $(24,48,72,96$ и $120 \mathrm{~h}$ инкубации). Для этого из пробирок, содержащих $3.3 \mathrm{mg}$ контейнеров с Гф и $0.7 \mathrm{~mL}$ воды, в нужный момент времени от суспензии отбирали аликвоту $60 \mu \mathrm{L}$, разбавляли ее 70\%-ным этанолом в 80 раз для растворения высвободившегося Гф и центрифугировали $2 \mathrm{~min}$ при $5000 \mathrm{rpm}$ для отделения микроконтейнеров. Концентрацию Гф в супернатанте определяли, измеряя интенсивность его флуоресценции в диапазоне 319-500 nm при возбуждении при $292 \mathrm{~nm}$ на приборе Synergy H1 (BioTek, США). Исходные пробирки с образцами ватерита с включенным Гф снова возвращали в эксперимент. Для каждой временной точки исследований проводили три независимых измерения, которые затем использовали для расчета стандартного отклонения.

На следующем этапе для растворения кристаллов Гф, появившихся в растворе после его высвобождения из контейнеров, использовали более эффективный, чем этанол, полярный органический растворитель ДМФА (ЭкоХимАналит, Россия). Для этого к каждому образцу, содержащему $3.3 \mathrm{mg}$ контейнеров с антимикотиком и $0.7 \mathrm{~mL}$ воды (водная суспензия ватеритных контейнеров c антимикотиком), непосредственно перед измерением спектров поглощения в нужный момент времени добавляли $0.7 \mathrm{~mL}$ ДМФА. Таким образом, соотношение ДМФА: $\mathrm{H}_{2} \mathrm{O}$ в результирующей смеси составляло $1: 1$ (vol\%). Полученную суспензию тщательно перемешивали в течение $2 \mathrm{~min}$ для растворения кристаллов Гф, центрифугировали 2 min при $5000 \mathrm{rpm}$ для отделения микроконтейнеров, отбирали аликвоту жидкой фазы и снимали спектры поглощения в стандартной кварцевой кювете $l=1 \mathrm{~cm}$ на спектрофотометре Shimadzu UV-1800 (Shimadzu, Япония). Для исключения неполного растворения Гф в растворе перед записью спектров аликвоту разбавляли смесью ДМФА: $\mathrm{H}_{2} \mathrm{O}$ в соотношении 1:1 в 100 раз. Максимум поглощения Гф в растворе ДМФА: $\mathrm{H}_{2} \mathrm{O}$ находился при длине волны $294 \mathrm{~nm}$. Для каждой временной точки исследований проводили три независимых измерения, которые затем использовали для расчета стандартного отклонения. Для каждого измерения использовали отдельную пробирку с образцом.

\section{Мониторинг состояния контейнеров методом спектроскопии комбинационного рассеяния}

Процесс деградации ватеритных контейнеров и высвобождение Гф из них в воде исследовали с помощью спектроскопии комбинационного рассеяния (КР), используя спектрометр Renishaw InVia (Renishaw, Великобритания) с объективом 50X/0.5 n.a., на длине волны лазера $532 \mathrm{~nm}$, мощностью $15 \mathrm{~mW}$ и CCD-детектором в диапазоне колебательных частот от 600 до $2000 \mathrm{~cm}^{-1}$. Погрешность положения пика была менее $0.1 \mathrm{~cm}^{-1}$ (калибровку системы перед измерениями проводили после лазерной термостабилизации с использованием эталонного образца кремния [26]. Идентификацию химического состава объектов проводили с использованием программного обеспечения спектрометра в матрице точек $10 \times 10$ с шагом $2 \mu \mathrm{m}$.

\section{Результаты и обсуждение}

Размер частиц ватерита, содержавших противогрибковый препарат Гф, был равен $1.1 \pm 0.3 \mu \mathrm{m}$, загрузка Гф в ватеритные контейнеры составила $200 \mu \mathrm{g}$ препарата на $1 \mathrm{mg}$ контейнеров. Измерение дзета-потенциала полученных контейнеров показало, что включение Гф в матрицу ватеритных частиц практически не повлияло на их электрокинетический потенциал, поскольку молекула Гф не имеет заряженных функциональных групп. Так, $\xi$-потенциал ненагруженных и нагруженных Гф частиц ватерита составил $-5.0 \pm 0.8 \mathrm{mV}$ и $-7.0 \pm 1.2 \mathrm{mV}$ соответственно. СЭМ-изображения полученных контейнеров представлены на рис. 1.

На рис. 2 представлены СЭМ-изображения контейнеров с антимикотиком, полученные через различные временные промежутки в ходе их инкубации в деионизованной воде. Изображения позволяют прослеживать структурно-морфологические изменения контейнеров. Необходимо принять во внимание, что незначительное количество свободных кристаллов Гф присутствует в исходном образце до начала эксперимента (рис. 2,a). Можно заметить, что через $24 \mathrm{~h}$ после начала инкубации образуются кубические кристаллы кальцита, свидетельствующие о начале процесса перекристаллизации метастабильных микрочастиц ватерита (рис. 2, b). Данный процесс завершался полным замещением фазы ватерита фазой кальцита через $72 \mathrm{~h}$ инкубации (рис. $2, d$ ). Вследствие того, что Гф нерастворим в воде, его высвобождение из ватеритных контейнеров сопровождалось агрегацией отдельных мелких частиц в крупные скопления кристаллов и их осаждением на протяжении всего эксперимента. На изображениях четко различимы такие кристаллы Гф. На вставке на рис. 2, $d$ представлены отдельные кристаллы Гф, дающие представление о его морфологии и позволяющие идентифицировать Гф на остальных СЭМ-изображениях. Небольшое количество кристаллов Гф было обнаружено также в исходном 

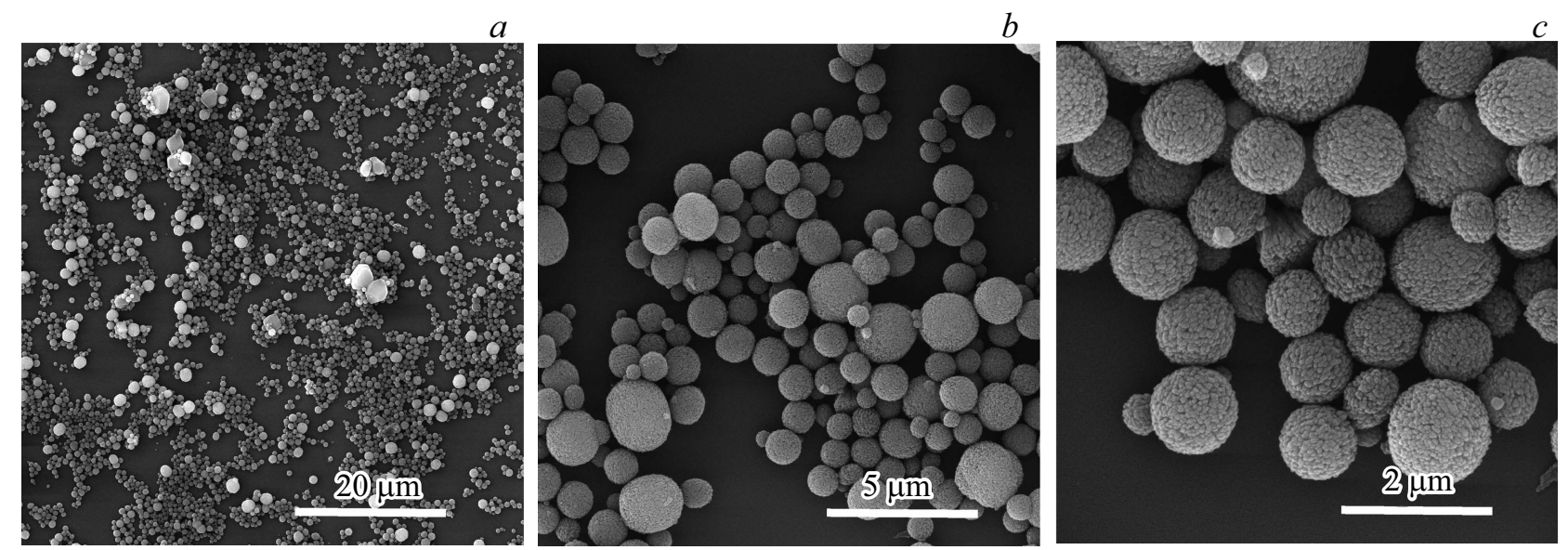

Рис. 1. СЭМ-изображения ватеритных контейнеров, содержащих противогрибковый препарат Гф.

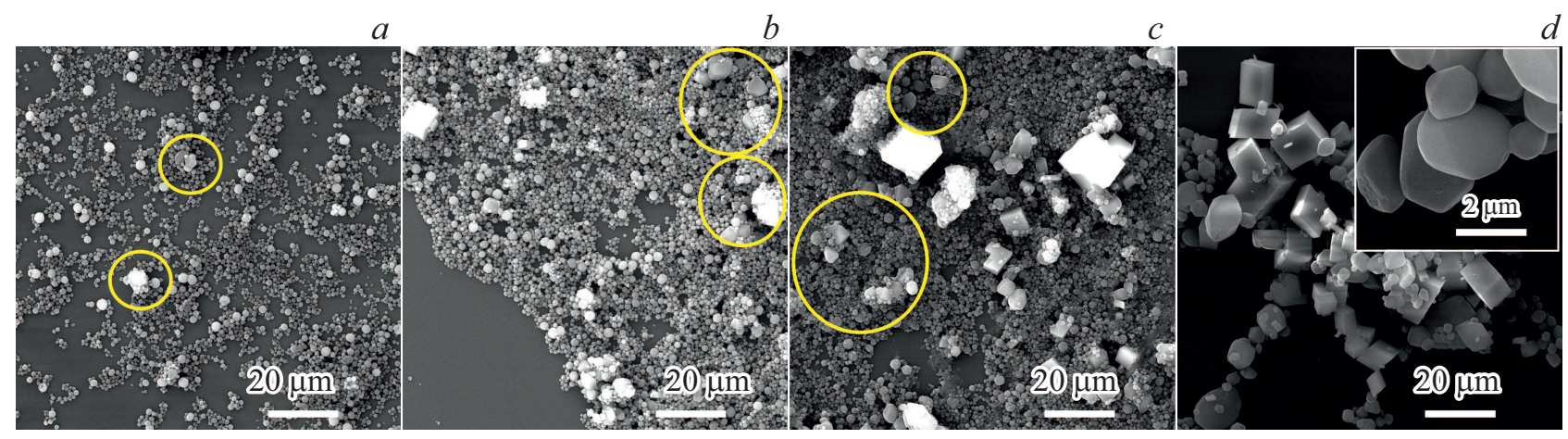

Рис. 2. СЭМ-изображения ватеритных контейнеров, содержащих противогрибковый препарат Гф, полученные в разные моменты времени в ходе инкубации в деионизованной воде: $5 \mathrm{~min}(a), 24(b), 48(c)$ и 72 h инкубации $(d)$. На вставке рисунка $d$ приведено увеличенное изображение отдельно лежащего кристалла Гф. Желтыми окружностями выделены области скопления кристаллов Гф.

образце (рис. $1, a)$ и через 5 min после начала эксперимента (рис. 2,a). С течением времени число таких кристаллов и их размер заметно увеличивались (рис. 2, $c, d$ ), отмечалась также их агрегация с частицами ватерита (рис. 2,c). Данные явления негативно сказываются на точности определения концентрации антимикотика в исследуемых суспензиях.

Таким образом, полученные данные выявили необходимость подбора растворителя, способного селективно переводить Гф в молекулярно-дисперсное состояние, для которого выполняется основной закон светопоглощения, справедливый для однородной и изотропной среды [27]. Для указанной цели апробировали два растворителя: протонодонорный этанол, который способен ограниченно растворять Гф за счет возможного образования водородной связи по шести атомам кислорода и атому хлора в его молекуле, и сильный сольватирующий растворитель ДМФА, способный хорошо растворять Гф [28], видимо, за счет большого дипольного момента молекулы.

На рис. 3 представлена калибровочная кривая, полученная для растворов Гф в 70\%-этаноле $(a)$, а также кривая кинетики высвобождения Гф из микрочастиц ватерита в воде, полученная при разведении проб в этаноле и последующего их флуориметрического определения $(b)$. Следует отметить, что интервал линейной зависимости интенсивности флуоресценции от концентрации Гф необычно узкий, что не характерно для этого метода и может быть связано с одновременным присутствием в растворе как молекул Гф, так и их агрегатов. Гризеофульвин имеет ограниченную растворимость в этаноле и, как следствие, инкубации проб в этаноле оказалось недостаточным для того, чтобы растворить его крупные агрегаты. Поэтому, как видно из рис. $3, b$, кривая отображает не кинетику процесса, а скорее, предельную растворимость Гф в данном растворителе.

В связи с этим для повышения растворимости Гф и, следовательно, правильности и точности определения его концентрации в супернатантах далее использовали более сильный растворитель ДМФА. Процедура проведения исследования описана выше в экспериментальной части. Данная процедура позволяла добиться максимального растворения кристаллов Гф, имеющихся в образце в конкретный момент времени.

На рис. 4, $а$ представлена калибровочная кривая, полученная для Гф в растворе ДМФА: $\mathrm{H}_{2} \mathrm{O}$ в соотношении 

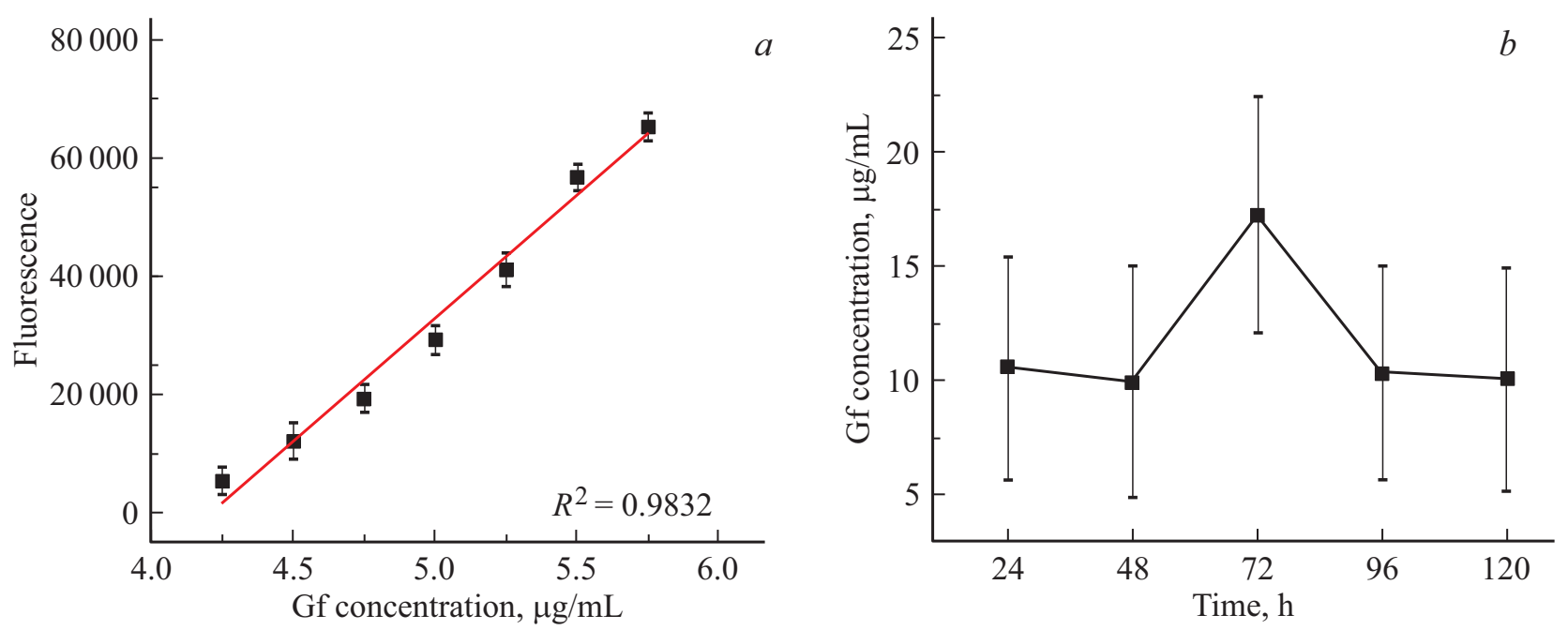

Рис. 3. Калибровочная кривая для определения концентрации Гф флуориметрическим методом в $70 \%$-этаноле, $\lambda_{\text {фл }}=413 \mathrm{~nm}$, $\lambda_{\text {возб }}=292 \mathrm{~nm}(a)$; зависимость концентрации Гф от времени при его высвобождении из ватеритных контейнеров в воде, полученная флуориметрическим методом по калибровочному графику при добавлении к водной суспензии контейнеров этанола $(b)$. Значения на кривых $(a)$ и $(b)$ представляют собой „среднее \pm стандартное отклонение“, рассчитанные на основе трех независимых измерений для каждой точки.
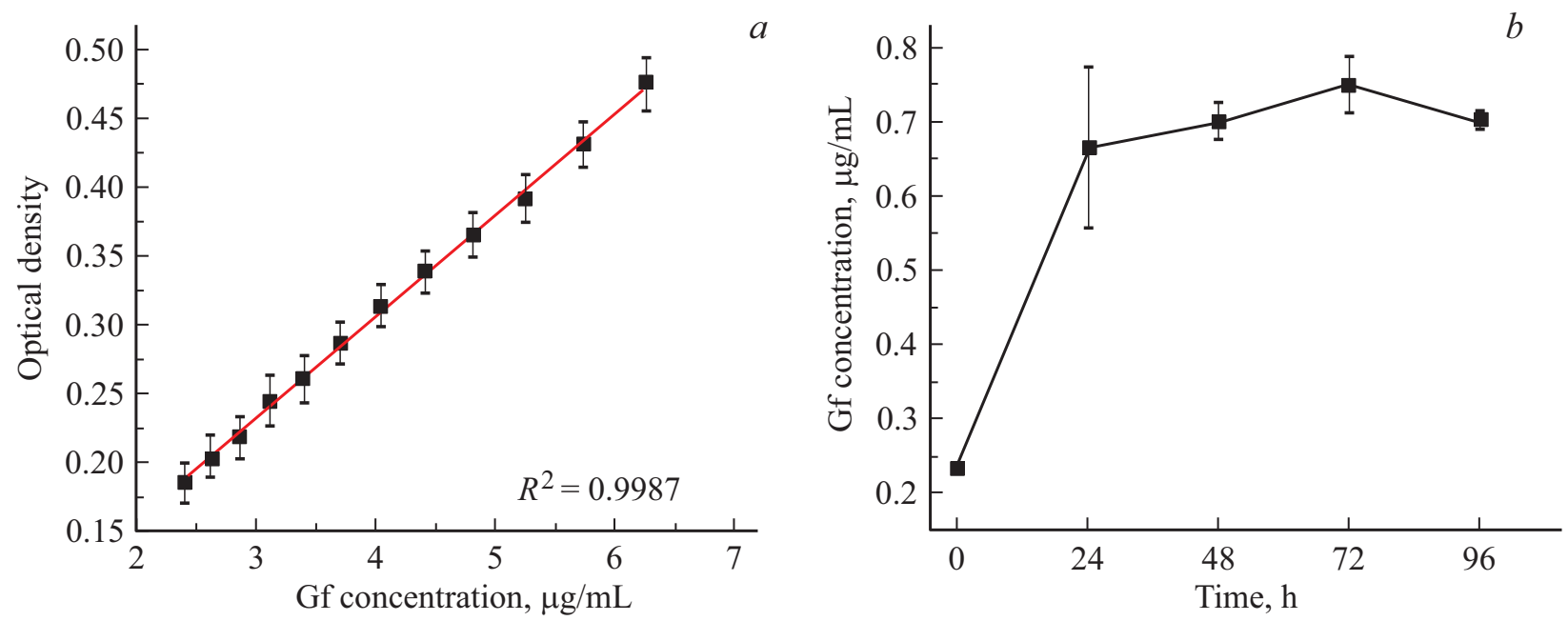

Рис. 4. Калибровочная кривая для определения Гф спектрофотометрическим методом в смеси ДМФА:Н $2 \mathrm{O}(1: 1)$, $\lambda_{\text {погл }}=294 \mathrm{~nm}(a)$; кинетическая кривая процесса высвобождения Гф из ватеритных контейнеров в воде, полученная спектрофотометрическим методом по калибровочному графику при добавлении к водной суспензии контейнеров ДМФА $(b)$. Значения на кривых $(a)$ и $(b)$ представляют собой „среднее \pm стандартное отклонение“, рассчитанные на основе трех независимых измерений для каждой точки.

$1: 1$ при измерении оптической плотности раствора в максимуме спектра при $\lambda_{\text {макс }}=294 \mathrm{~nm}$. Важно отметить, что в случае ДМФА: $\mathrm{H}_{2} \mathrm{O}$ калибровочная кривая демонстрирует более линейный характер в большем диапазоне концентраций Гф и имеет лучший коэффициент аппроксимации, чем в случае 70\%-этанола, где флуктуации точек относительно аппроксимирующей прямой свидетельствуют о флуктуациях концентраций Гф в растворе вследствие его худшей растворимости (рис. 3,a). В УФ спектре Гф, приготовленном в растворе ДМФА: $\mathrm{H}_{2} \mathrm{O}$, имелись характерные максимумы поглощения при 260,
$294 \mathrm{~nm}$, плечо в области 315-360 nm и минимум при $272 \mathrm{~nm}$.

На рис. 4, $b$ представлена кривая кинетики высвобождения Гф в воде, полученная путем добавления к водной суспензии контейнеров ДМФА и последующего спектрофотометрического определения Гф в полученном растворе. Установлено, что Гф с наибольшей скоростью растворяется в первые $24 \mathrm{~h}$, на насыщение кинетическая кривая выходила после $72 \mathrm{~h}$ инкубации. Это согласуется с изменениями, представленными на СЭМ-изображениях (рис. 2, $d$ ), свидетельствующими о 

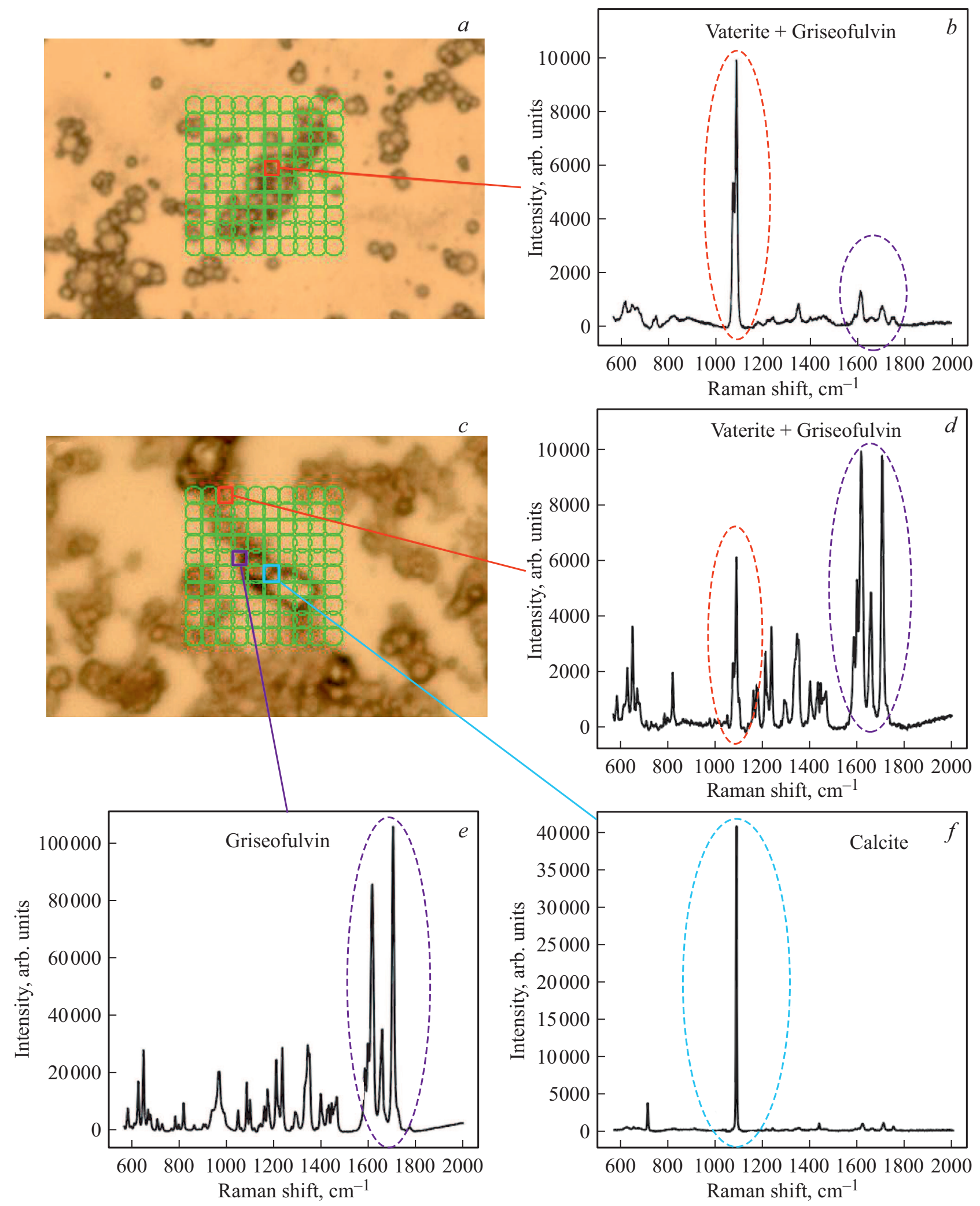

Рис. 5. Изображения ватеритных контейнеров, содержащих противогрибковый препарат Гф в начальный момент времени $(a)$ и через $48 \mathrm{~h}$ инкубации в воде $(c)$. Соответствующие спектры КР, полученные при исследовании ватеритных контейнеров, содержащих противогрибковый препарат Гф в начальный момент времени $(b)$ и через $48 \mathrm{~h}$ инкубации в воде $(d, e, f)$. 
полном переходе ватерита в кальцит спустя $72 \mathrm{~h}$ инкубации в воде. Такой процесс перекристаллизации частиц всегда сопровождается практически полным высвобождением вещества, иммобилизованного в объем исходной ватеритной матрицы [29].

Таким образом, можно сделать вывод, что при данных условиях эксперимента в ходе инкубации ватеритных контейнеров в воде полное высвобождение Гф, иммобилизованного в ватеритные контейнеры, происходит через $72 \mathrm{~h}$, и при этом напрямую связано с процессом их перекристаллизации в кальцит, который практически не соосаждает Гф. Данное обстоятельство свидетельствует о том, что основная масса Гф в исходном образце была заключена в матрицу частиц ватерита, а инкубация в воде стимулировала его высвобождение, агрегацию и осаждение в виде кристаллов, как видно из СЭМ-изображений (рис. 2).

Для подтверждения факта изменения полиморфной модификации карбоната кальция (перекристаллизации ватерита в кальцит) и высвобождения препарата Гф из частиц ватерита в процессе инкубации контейнеров в воде, были исследованы КР-спектры полученного образца. На рис. 5 представлены спектры контейнеров, снятые в начальный момент времени (рис. 5, a), а также через $48 \mathrm{~h}$ инкубации в воде (рис. 5,c).

Спектр КР ватеритных контейнеров с Гф до инкубации (рис. 5,a) содержал ряд пиков, в числе которых стоит выделить интенсивный пик ватерита с волновым числом $1090 \mathrm{~cm}^{-1}$ (выделен красной пунктирной линией, рис. 5, b) [30,31], а также менее интенсивные пики Гф с волновыми числами в диапазонах $600-800 \mathrm{~cm}^{-1}$ и $1600-1800 \mathrm{~cm}^{-1}$ (выделены фиолетовой пунктирной линией, рис. $5, b)$ [32,33]. Спустя 48 h инкубации контейнеров в воде на видимом изображении были выявлены морфологические изменения в образце: четко обозначилось присутствие кристаллов Гф, частиц кальцита, а также сферических ватеритных контейнеров с Гф, для которых не произошла перекристаллизация в кальцитную модификацию. Полученные результаты полностью согласуются с данными, полученными методом СЭМ (рис. 2, c). Измерение КР-спектров для каждой из указанных фаз подтвердило наличие структурных изменений в образце (рис. 5,c). Так, в КР-спектрах, полученных для сферических частиц (спектр „Vaterite+Griseofulvin“ на рис. 5,d), были выявлены интенсивные пики Гф и менее интенсивный пик ватерита. Характерные пики Гф были также найдены в КР-спектрах, снятых с кристаллов свободного Гф (спектр „Griseofulvin“ на рис. $5, e)$. В то же время спектры, снятые с кубических частиц карбоната кальция („Calcite“ на рис. 5,f), обладали ярким характерным пиком кальцита с волновым числом $1088 \mathrm{~cm}^{-1}$ [34], а пики Гф в них отсутствовали.

\section{Выводы}

Спектроскопическими методами в модельном варианте изучен процесс высвобождения противогрибкового препарата Гф, иммобилизованного в микроконтейнеры ватерита, в водном растворе, который может иметь место при введении таких носителей для лечения пациента. При сравнении протонодонорного этанола и апротонного ДМФА, вводимых в водную суспензию микроконтейнеров, показано, что использование в качестве растворителя ДМФА позволяет полностью перевести в раствор весь высвобождающийся Гф, что было положено в основу методики его спектрофотометрического определения в супернатанте при деградации во времени кристаллов ватерита. Изучена кинетика процесса высвобождения водонерастворимого вещества в деионизованной воде из контейнеров на основе частиц карбоната кальция в ватеритной модификации и показано, что полное высвобождение антимикотика происходит через $72 \mathrm{~h}$, что согласуется с данными, полученными методом КР-спектроскопии и СЭМ. На основе полученных результатов можно сделать вывод, что данный метод позволяет изучать поведение и характер кинетики высвобождения гидрофобного препарата из ватеритного микроконтейнера в водной среде. Применение данной методики представляется также перспективным для исследования кинетики высвобождения лекарств из систем доставки, для которых характерна высокая устойчивость в воде (например, галлуазитные или цеолитные носители, пористые частицы диоксида кремния). Предложенная методика для детектирования и исследования высвобождения из контейнеров-носителей в водной среде может быть адаптирована к широкому ряду лекарственных препаратов, которые нерастворимы в воде, включая как другие типы антимикотиков (нистатин), так и антибиотики (эритромицин) и антибактериальные препараты (нитрофурал). Результаты, полученные спектроскопическими методами, представляют большой практических интерес для фармацевтики и биомедицинского материаловедения, а именно для повышения эффективности, биодоступности и безопасности лекарственных препаратов, а также для разработки и усовершенствования носителей и систем для адресной доставки.

\section{Благодарности}

Авторы выражают благодарность В.С. Аткину за помощь в проведении СЭМ.

\section{Финансирование работы}

Исследование выполнено при поддержке Министерства науки и высшего образования Российской Федерации в рамках Госзадания (№ FSRR-2020-0002). 


\section{Конфликт интересов}

Авторы заявляют, что у них нет конфликта интересов.

\section{Список литературы}

[1] Беликов В.Г. // Рос. хим журн. 2002. T. XLVI. № 4. C. $52-56$.

[2] Khoshayand M.R., Abdollahi H., Shariatpanahi M., Saadatfard A., Mohammadi A. // Spectrochim. Acta A. 2008. V. 70. N 3. P. 491-499.

[3] Государственная фармакопея Российской Федерации. Изд. 14-е. 7.1.[Электронный ресурс] Режим доступа: http://femb.ru/femb/pharmacopea.php

[4] Электронный ресурс. Режим доступа: https://apps.who.int/phint/2019/index.html\#p/home

[5] Электронный ресурс. Режим доступа: https://www.usp.org/

[6] Bhakay A., Rahman M., Dave R., Bilgili E. // Pharmaceutics. 2018. V. 10. N 3. P. 86.

[7] Zhu P., Zhou L., Song Y., Cai L., Ji M., Wang J., Ruan G., Chen J. // J. Mat. Chem. B. 2020. V. 8. N 22. P. 4899-4907.

[8] Prasad R., Dalvi S.V. // Cryst. Growth Des. 2019. V. 19. N 10. P. 5836-5849.

[9] Wani R.J., Sharma P., Zhong H.A., Chauhan H. // ASSAY Drug Dev. Techn. 2020. V. 18. N 3. P. 109-118.

[10] Aggarwal N., Goindi S. // Int. J. Pharm. 2012. V. 437. N1-2. P. 277-287.

[11] Marto J., Vitor C., Guerreiro A., Severino C., Eleutério C., Ascenso A., Simões S. // Coll. Surf. B: Bioint. 2016. V. 146. P. 616-623.

[12] Schreier H., Bouwstra J. // J. Control. Release. 1994. V. 30. N 1. P. $1-15$.

[13] Patel R., Patel H., Baria A. // Int. J. Drug Deliv. Technol. 2009. V. 1. N 2. P. $42-45$.

[14] Hussain A., Samad A., Singh S.K., Ahsan M.N., Haque M.W., Faruk A., Ahmed F.J. // Drug. Deliv. 2016. V. 23. N 2. P. 642-657.

[15] Shishoo C., Chudasama A., Patel V., Nivsarkar M., Vasu K. // J. Adv. Pharm. Technol. Res. 2011. V. 2. N 1. P. 30.

[16] Rajpoot P., Pathak K., Bali V. // Recent. Pat. Drug. Deliv. Formul. 2011. V. 5. N 2. P. 163-172.

[17] Verma P., Pathak K. // Nanomedicine: NBM. 2012. V. 8. N 4. P. 489-496.

[18] Jain S., Jain S., Khare P., Gulbake A., Bansal D., Jain S.K. Drug. Deliv. 2010. V. 17. N 6. P. 443-451.

[19] Firooz A., Nafisi S., Maibach H.I. // Int. J. Pharm. 2015. V. 495. N 1. P. 599-607.

[20] Gusliakova O.I., Lengert E.V., Atkin V.S., Tuchin V.V., Svenskaya Yu.I. // Opt. Spectrosc. 2019. V. 126. N 5. P. 539-544.

[21] Lengert E., Verkhovskii R., Yurasov N., Genina E., Svenskaya Y. // Mat. Lett. 2019. V. 248. P. 211-213.

[22] Gusliakova O., Verkhovskii R., Abalymov A., Lengert E., Kozlova A., Atkin V., Nechaeva O., Morrison A., Tuchin V., Svenskaya Y. // Mater. Sci. Eng. C. 2021. V. 119. P. 111428.

[23] Kumar L., Verma S., Bhardwaj A., Vaidya S., Vaidya B. // Artif. Cells Nanomed. Biotechnol. 2014. V. 42. N 1. P. 32-46.

[24] Jambhrunkar S., $Q u$ Z., Popat A., Karmakar S., Xu C., Y C. // J. Colloid Interface Sci. 2014. V. 434. P. 218-225.
[25] Verkhovskii R.A., Lengert E.V., Saveleva M.S., Kozlova A.A., Tuchin V.V., Svenskaya Yu.I. // Opt. Spectrosc. 2020. V. 128. N 6. P. $799-808$.

[26] Dashty M. // Diabetes Metab. 2016. V. 7. N 7. P. 1-9.

[27] Фетисов Г.В, Алов Н.В, Василенко И.А. Аналитическая химия. Т. 2 Инструментальные методы анализа. Часть $1 /$ Под ред. Ищенко А.А. М.: ФИЗМАТЛИТ, 2019. 472 с.

[28] Электронный ресурс. Режим доступа: URL: https://xumuk.ru/encyklopedia/1151.html

[29] Svenskaya Yu.I., Parakhonskiy B.V., Haase A., Atkin V., Lukyanets E., Gorin D.A., Antolini R. // Biophys. Chem. 2013. V. 182. P. $11-15$.

[30] Kontoyannis C.G., Vagenas N.V. // Analyst. 2000. V. 125. N 2. P. 251-255.

[31] Wehrmeister U., Soldati A.L., Jacob D.E., Häger T., Hofmeister W. // J. Raman Spectrosc. 2010. V. 41. N 2. P. 193-201.

[32] Zarów A., Zhou B.O., Wang X., Pinal R., Iqbal Z. // Appl. Spectrosc. 2011. V. 65. N 2. P. 135-143.

[33] Smith G.P.S., Huff G.S., Gordon K.C. // Spectroscopy (Springf). 2016. V. 31. N 2. P. 42-50.

[34] Zhang X., Guo J., Wu S., Chen F., Yang Y. // Sci. Rep. 2020. V. 10. N 1. P. 168. 